\title{
高齢者の生活環境と住環境の評価に関する考察 \\ A STUDY ON EVALUATION BETWEEN LIFE ENVIRONMENT OF THE ELDERLY AND HOUSING ENVIRONMENT
}

\author{
齋 藤 芳 徳*, 外山 義** \\ Yoshinori SAITO and Tadashi TOYAMA
}

\begin{abstract}
The purpose of this study is to clarify evaluation between life environment of the elderly and housing environment. This is based on the results of the questionnaire given to the elderly in A-City and rehabilitation hospital. The results of analysis are as follows. 1)A feeling of satisfaction of the life environment of the elderly and the housing environment is more sufficiently than the non-elderly. 2)A feeling of satisfaction of the housing environment of the elderly of residential home is more sufficiently than the elderly of home. 3)A feeling of satisfaction of the life environment of the handicapped elderly and the housing environment is more insufficiently than the elderly. 4)Evaluation of life environment has a connection with evaluation of housing environment.
\end{abstract}

Keywords : evaluation of life environment, evaluation of housing environment, the elderly, residential home, the handicapped elderly 生活環境評価、住環境評価、高齫者、老人ホーム、高齢障害者

1.はじめに

\section{1-1. 研究の背景と目的}

現在、在宅福祉が推進されている中で、高制者が住み慣れた地 域に住み続けられることは極めて重要であり、在宅生活を支障な く過ごしていくためには良質な住環境を整備することが基本とな る。そして、良質な住環境において快適な生活を享受できる可能 性を得ることは、生活領城が次第に狭くなりがちな高齢者の生活 を、安心かつ豊かなものにする。快適で良質な住環境を整備する ためには、高齢者の住噮境の要求を探ることが求められ、その際 は生活要求との関保で検討される必要があると指摘されている1”。

生活要求を捉えようとする代表的な手法は QOL（Quality of Life）の測定法である。QOL の要素は、健康、教育、㕍用、余樶、 所得、環境、犯罪、家族等が举げられており ${ }^{2) 、 ま た 、 Q O L は さ ~}$ まざまな分野でさまざまな目的に使われているためにその概念も 多様である。本稿では、在宅福祉の推進に伴って、障害を持つ高 踰者が在宅で生活する機会が増えること等の理由で、高路障害者 を調查対象に加えている関係から、リハビリテーション分野の QOL の既往研究をレビューした。虚弱な高龄者の QOL の研究に 関していえほ、1980 年代まではQOL を総合的に把握する NHP ${ }^{3)}$ 、
SIP $^{4)} 、$ OARS $^{5)}$ 等の多くの測定法が開発された。その後、疾患別 のQOL ${ }^{6)}$ が治療効果判定の指標として開発される傾向を強めてい る反面 ${ }^{2} 、$ QOL の測定法が治療効果の判定に有効な評価項目に偏 重しているために混乱を招く恐れがあるとして、QOL という用語 を使用すべきではないという指摘等もみられる ${ }^{8)}$ 。

一方、住環境への要求に関する既往研究として、建築計画の分 野では、梶 ${ }^{9)} や$ 青木ら $^{10)}$ の研究から今日に至るまでさまざまな研 究が行われてきた。そのうち、住環境を評価の対象とし、快適性 に関する研究で、居住者の意識面を重視したものは、高橋ら ${ }^{11)} の$ 研究があげられる。しかし、高跲者を対象にして生活要求と住睘 境への要求の関係を総合的に探ろうとした研究は、従来必ずしも 十分になされてこなかった。

このような背景をふまえ、本稿では高齢者の生活環境 ${ }^{12)}$ と住環 境に注目し、在宅高齢者・施設居住高齢者・リハビリテーション 病院通院高跲者及び非高跲者の生活環境と住環境に関する主観的 な評価を基に、各集団の(1)生活環境と住環境の評価の実態を把握 し、(2)評価の違いが生じる要因を探るとともに、(3)生活環境評価 と住環境評価の関係について考察することを目的としている。

\footnotetext{
* 京都大学大学院工学研究科 大学院生・修士(地域政策)

Graduate Student, Graduate School of Engineering, Kyoto Univ.

** 京都大学大学院工学研究科 教授・工博 


\section{1-2. 研究の方法}

研究のフレームは、図 1 に示すとおりである。各集団の特性を 明らかにするために、(1) K 町（在宅高齢者 $\times$ 施設居住高齢者）、 (2) $\mathrm{F}$ 町（在宅高齢者 $\times$ 非高跉者）、(3)在宅高齢者間（F 町 $\times \mathrm{K}$ 町 メリハビリテーション病院）で、主に面接聴取法によるアンケー 卜調查を基に、各集団の主観的な評価を比較分析することにより、 生活環境と住環境の評価の実態を把握し、評価の違いが生じる要 因を探り、生活環境評価と住環境評価の関係について考察した。

\section{2. 調査の概要}

\section{2-1. 調查地域}

1) $\mathrm{A}$ 市 $\mathrm{K}$ 町

・調查期間：1997年 7 10月

・調查方法 : 面接聴取法 (一部留置き法)

・町内会名簿から無作為に抽出した在宅の 60 歳以上の男女（以

下、 $\mathrm{K}$ 町在宅高龄者）と施設管理者を通じて対象者を選出した 軽費老人ホーム $\mathrm{A}$ 型に居住する 60 歳以上の男女（以下、 $\mathrm{K}$ 町 施設高齢者)

2) $\mathrm{A}$ 市 $\mathrm{F}$ 町

・調查期間 : 1997年 6 月 7月

・調查方法 : 面接聴取法 (一部留置き法)

-調查対象 : 調查対象 : 町内会名簿から無作為に抽出した在宅の 60 歳以上の男女（以下、 $\mathrm{F}$ 町在宅高龄者）と主対象を主婦とし た 60 歳未満の男女 (以下、 $F$ 町非高踰者)

3）リハビリテーション科をもつ病院 ${ }^{13)}$ （以下、リ八病院）

・調查期間：1997年 7 10月

・調查方法 : 面接聴取法

・調査対象 : 施設管理者を通じて対象者を選出したり八病院に通 院している在宅の 60 歳以上の男女（以下、リ八病院高齢者）

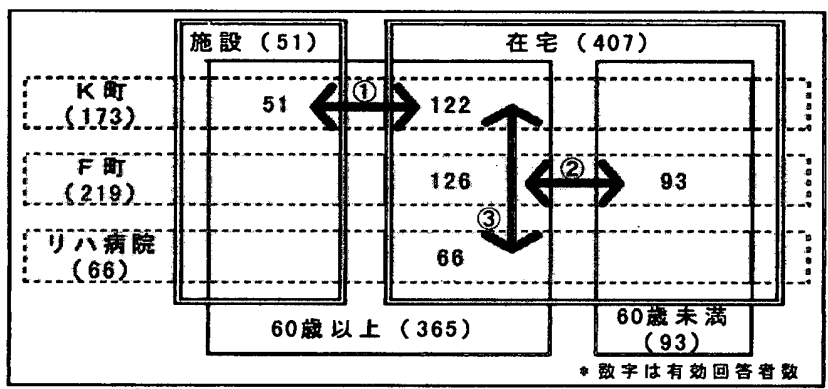

图1 研究のフレーム

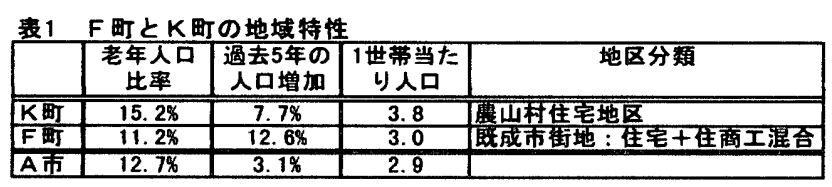

\section{带2 模本数および回収数}

\begin{tabular}{|c|c|c|c|c|c|c|}
\hline \multicolumn{2}{|c|}{ 諨奋地域 } & 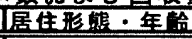 & 樶本数 & 回收数 & 回收裹 & 借者 \\
\hline \multirow{4}{*}{$\begin{array}{l}\text { A } \\
\text { 市 }\end{array}$} & K 町 & 在宅・高酫者 & 190 & 122 & $64.2 \%$ & 60 泼以上 \\
\hline & & - 重䲞 & 56 & 51 & $91.1 \%$ & 軽矤老人末 \\
\hline & F 町 & 在宅・高蓠者 & 240 & 126 & $52.5 \%$ & 60丽以上 \\
\hline & & 在宅 - 非高岭者 & 240 & 93 & $38.8 \%$ & 60歳末満 \\
\hline \multirow{2}{*}{\multicolumn{2}{|c|}{ リ八质院 }} & 在宅・高倫者 & 79 & 66 & $83.5 \%$ & 60 佱以上 \\
\hline & & 酉就 & 559 & 285 & $56.9 \%$ & \\
\hline
\end{tabular}

*回叹数では、回収しても未回答の調査買は除いている。
夜3 生活環境觯価項目

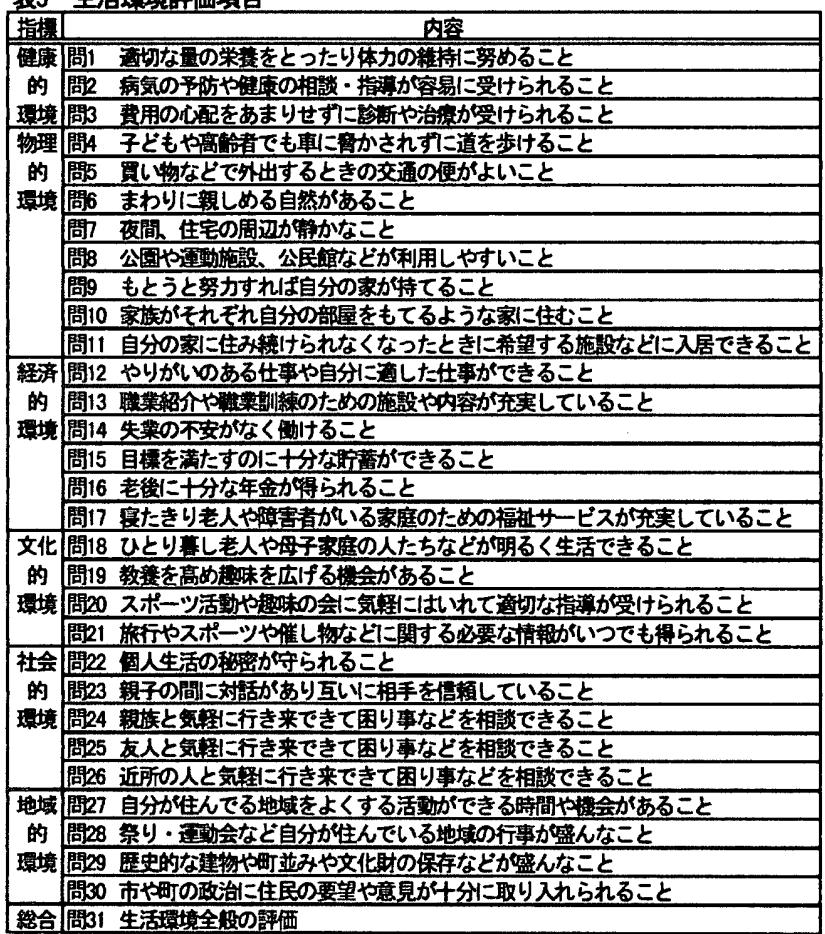

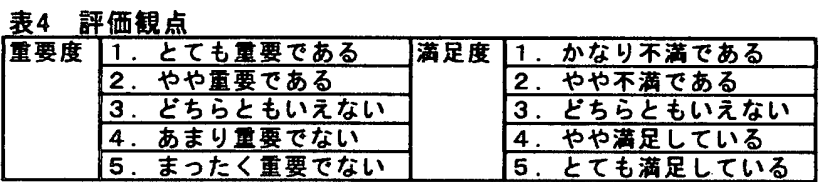

表5 住環境鮃価項目

\begin{tabular}{|c|c|}
\hline 場所筑 & 内容 \\
\hline \multirow[t]{3}{*}{ 床 } & 問1 晹居などに段筹がないこと \\
\hline & 闆2 咠い敖物やめくれやすい敖物がないこと \\
\hline & 閣3 浴害などでは、ぬれても滑りにくいこと \\
\hline \multirow[t]{2}{*}{ 嚲 } & 罟4 ぶつかりやすい䦨害物がないこと \\
\hline & 問5 体を支えるための手すりがついていること \\
\hline \multirow[t]{2}{*}{ 出入口 } & 間6 梗イスでも通行できる出入口の蝠があること \\
\hline & 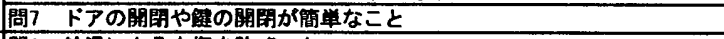 \\
\hline \multirow[t]{2}{*}{ 給水 } & 圆8 給晹による火鹪を防ぐこと \\
\hline & 問9 水栓が回しやすいこと \\
\hline \multirow{3}{*}{ 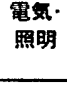 } & 問10 使いやすい䯧さにスイッチやコンセントがあること \\
\hline & 問11 夜間トイレに起きるとき、スイッチの位貫がかかりやすいこと \\
\hline & 問12 垔内が明るく、ものが見やすいこと \\
\hline \multirow{3}{*}{$\begin{array}{l}\text { 連絡· } \\
\text { 電話 }\end{array}$} & 閭13 急に体眮が重くなったときに勖けが呼べること \\
\hline & 间14 奄話の呼び出し音や相手の声がよく周こえること \\
\hline & 問15 電鮕のダイヤルが回しやすいことや受䀨器が持ちやすいこと \\
\hline \multirow{3}{*}{$\frac{\text { 椧暖閶 }}{\text { 玄閔 }}$} & 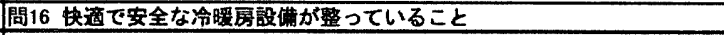 \\
\hline & 問17 道路から玄関までに段差がないこと \\
\hline & 閭18 上りかまちが暴降しやすいこと \\
\hline \multirow{3}{*}{$\begin{array}{l}\text { 部下: } \\
\text { 睹段 }\end{array}$} & 畻19 照明や监光テーブなどで、段差がわかりやすいこと \\
\hline & 固20 手すりなどで、眣段が昇降しやすいこと \\
\hline & 問21 車イスでも通行できる廊下の辐があること \\
\hline \multirow{6}{*}{$\begin{array}{l}\text { 澄室· } \\
\text { 脱衣 }\end{array}$} & 聞22手すりなどで、浴橧の出入りがしやすいこと \\
\hline & 問23 脱衣室と浴室の間に急激な温度姜がないこと \\
\hline & 問24 浴室内の媵抚けや浴措が見やすいこと \\
\hline & 固25 脱衣室と浴室の段美がないこと \\
\hline & 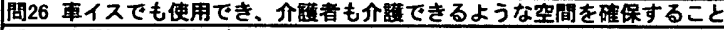 \\
\hline & 問27 洗篧機や乾㜭機が使いやすいこと \\
\hline \multirow[t]{3}{*}{ H化 } & 䦖28 手すりなどで、便厘が乗り降りしやすいことや使い腾手がよいこと \\
\hline & 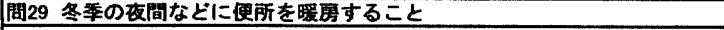 \\
\hline & 問30 車イスでも使用でき，介厰者も介護できるような空間を磪保すること \\
\hline \multirow[t]{4}{*}{ 落室 } & 問31 床からの立ち上がりが簡些なこと \\
\hline & 䦓32 トイレの位置が近いこと \\
\hline & 問33 衣服の収納などが简単なこと \\
\hline & 問34 静かな環㙋であること \\
\hline \multirow[t]{3}{*}{ 台所 } & 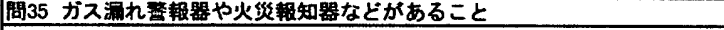 \\
\hline & 問36 イスに座って、ヌは車イスで作莱ができること \\
\hline & 問37 食照の収納などが簡単なこと \\
\hline 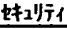 & 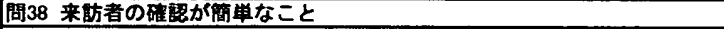 \\
\hline 線合 & 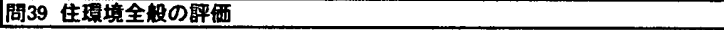 \\
\hline
\end{tabular}


なお、 $\mathrm{A}$ 市全体を基準にしたときの $\mathrm{K}$ 町と $\mathrm{F}$ 町の地域特性を表 1 に ${ }^{14)}$ 、本調查の標本数および回収数を表 2 に示す。

\section{2-2. 調查内容}

1）回答者の属性 : 性別、年齔、家族構成、職業、健康状態、住居形 態、居住年数

2）生活環境評価 : 既往研究 ${ }^{15)}$ 等を参考に、生活環境の評価項目及 び評価観点は、健康的・物理的・経済的・文化的・社会的・地域 的の 6 指標・ 30 項目・2 観点を選定した。評価項目を表 3 に、評 価観点を表 4 に示す。

3）住環境評価 : 既往研究 ${ }^{16)}$ 等を参考に、住環境の評価項目及び評 価観点は、住宅内の 14 の場所・部位から 38 項目を選定した。評 価項目を表 5 に示寸。なお、評価観点は生活環境評価と同様であ る。

\section{2-3. 回答者の属性}

調查対象者の属性は表 6 のとおりである。K町の在宅高龄者と施 設高龄者の属性を比較すると、「家族構成」「住居形態」「居住年 数」が異なる。F町の在宅高齢者と非高齡者では、「性別」「年齢」 「家族構成」「居住年数」に違いがみられる。在宅高齢者間では、 $\mathrm{K}$ 町と F町は「家族構成」「居住年数」にやや違いがみられ、リハ 病院高齢者は「健康状態（特に「手足の障害」）」の違いが顕著て あるが、他の属性はF 町在宅高龄者と類似した傾向である。なお、 回答した高齢者の 67\%が「75 歳以上」である。

\section{3. 生活懪境評価の結果}

まず、高齢者及び各集団の生活環境評価の傾向を把握し、次に図 1の(1) (3)について、(1)と(2)は独立 2 標本の $\mathrm{t}$ 険定、(3)については

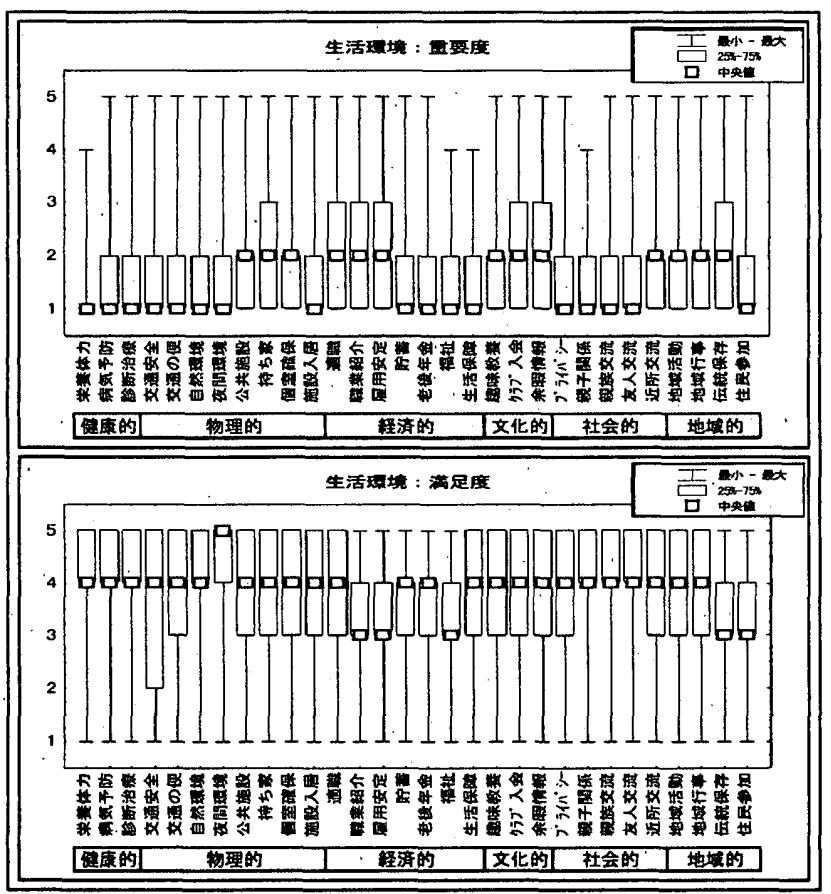

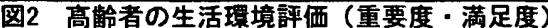

一元配置の分散分析により比較分析を行った ${ }^{17)}$ 。表 7に各集団間の 比較分析結果を示す。なお、(1)（3)の分析結果については有意とな った項目が多いため、主に有意水準 1\%末満（P<0.01）の項目につ いて考察している（住環境評価も同様である）。

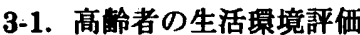

高龄者の生活環境評価をみると（図 2）、重要度の各項目の中央 值は「とても重要である」「やや重要である」という肯定的な評価

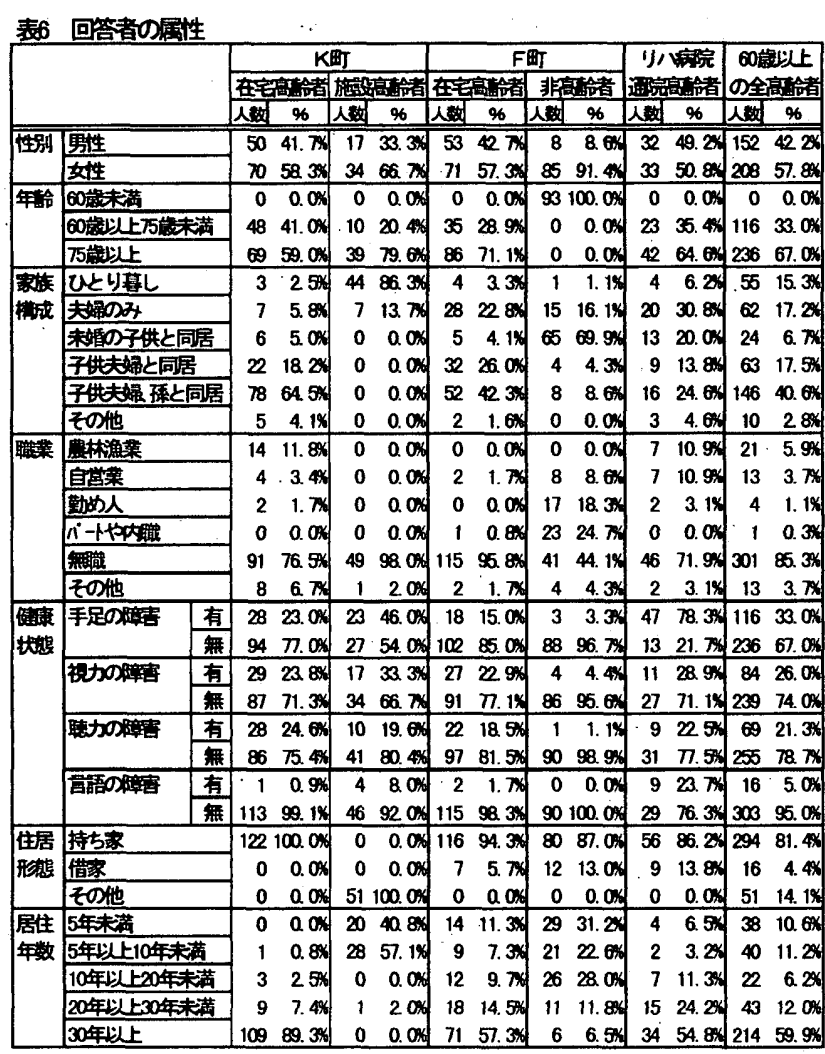

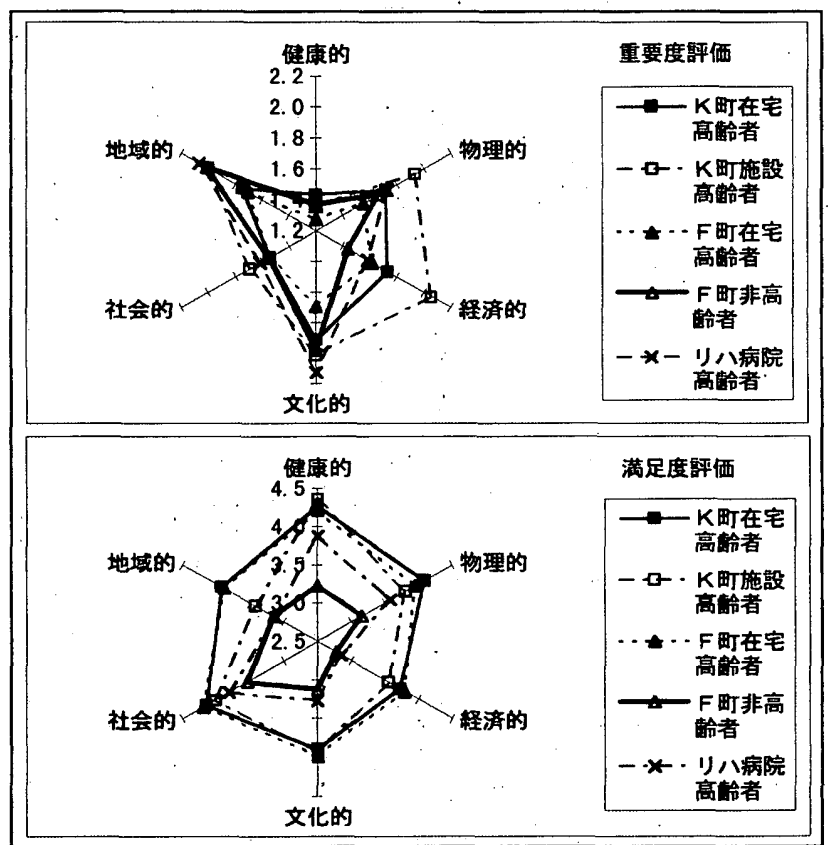

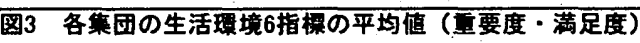


である。满足度の各項目の中央值も「やや満足している」という肯 定的な評価が多数であるが、「問 13 職業紹介」「問 14 雇用の安定」

「問 17 福祉サービス」「問 29 伝統保存」「問 30 住民参加」の満 足度がやや低い。とりわけ、「福祉サービス」は重要度が高く満足 度が低いことから、福祉サービスに不満を感じている高䞒者が多い ことがわかる。

重要度を指標別に比較すると、相対的に健康的環境と社会的環境 の評価が高く、物理的環境と経済的環境は項目間で評価のばらつき がみられ、文化的環境と地域的環境はやや低い評価である。満足度 では、経済的環境と地域的環境に低い評価の項目がみられる。

各集団を指標別に比較寸ると（図 3）、重要度では「健康的環境」 が各集団ともに高い評価であり、「経済的環境」の評価には開きが みられる。满足度では、相対的にF町非高龄者の满足度が低く、障 害を持つリ八病院高跲者よりも満足度が低い。この結果は、主観的 な QOL 評価に関しては障害者や高䠲者の満足感は低くないという 報告 ${ }^{18)}$ と同様の結果であり、障害者や高齢者であることが、そのま ま生活環境評価の低下にはつながらないことが示されている ${ }^{19)}$ 。

\section{3-2. K町（在宅高龄者 $\times$ 施設高龄者）の生活棵境評伍}

重要度評価では（表 7）、「問 8 公共施設」「問 9 持ち家」「問 13 職業紹介」「問 15 十分な貯蓄」「問 25 近所交流」「問 27 地域 活動」で平均值に差がみられ、差のあるすべての項目で在宅高齢者 の重要度が高い。自分の家を持つこと、可能な限り仕事を続けるこ と、金銭的に余裕を持つこと、地域の人々とふれあいながら生活す ること、等を在宅高龄者が重要視している傾向がみられる。

満足度評価では、「問 8 公共施設」「問 9 持ち家」「問 10 個室 の確保」「問 12 適職」「問 14 雇用の安定」「問 27 地域活動」「問 29 伝統保存」「問 30 住民参加」で平均值に差がみられ、重要度同
様、差のあるす心゙ての項目で在宅高跲者の満足度が高い。また、「地 域活動」「伝統保存」「住民参加」の地域的環境の满足度の差は、 施設高齢者の転居後の新たな地域社会への参加が難しい現状にある ことを示唆している。なお、施設は個室であるために「問 22 プラ イバシ一」の满足度は高いものの $(\mathbf{P}<\mathbf{0 . 0 5}) 、 「$ 個室の確保」の满 足度は低い。この施設高齢者の満足度の違いは、施設での個室の整 備が入居者の満足度の向上に単純に結びつくものではなく、满足度 の向上を目指すには、「個人的領域形成」 ${ }^{20)}$ 等に配慮した居住空間 つくくりが必要であることを示していると思われる。

\section{3-3. F町（在宅高峆者 $\times$ 非高朎者）の生活聚境評価}

重要度評価において平均值に差がみられた項目のうち（表 7）、 「問 8 公共施設」「問 19 趣味・教養」「問 26 近所交流」「問 27 地域活動」「問 28 地域行事」は在宅高龄者の重要度が高く、K 町

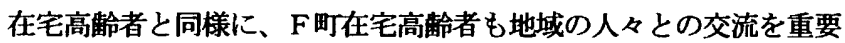
視している傾向がみられる。一方、「問 12 適職」「問 14 雇用の安 定」「問 23 親子関係」は非高齢者の重要度が高く、「壮年期では 家族関係、社会的交流、就労、家族の荃育などが QOLに影響する」 21) という報告と同様の傾向がみられる。

満足度評価では、問 1 30の全項目で平均值に差がみられ、すべ ての項目で在宅高齢者の满足度は非高雅者の满足度よりも高く ${ }^{22)}$ 、 ここでも、主観的な評価に関しては、高跲者であることがそのまま 生活環境評価の低下にはつながらないことが示されている。

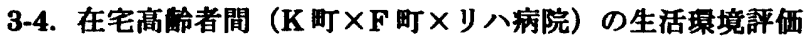

在宅高踰者間の生活環境評価の特徵は（表 7)、リ八病院高龄者 と $\mathrm{K}$ 町・F 町在宅高跉者の評価の違いである。リ八病院高跲者の重 要度が高い項目は、「問 16 老後の年金」「問 17 福祉サービス」

衰7 生活罢境評価の比較分析結果（重要度・满足度）

\begin{tabular}{|c|c|c|c|c|c|c|c|c|c|c|c|c|c|c|c|c|c|c|c|c|c|c|}
\hline & \multirow{2}{*}{\multicolumn{4}{|c|}{ 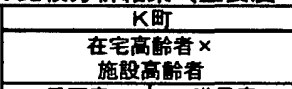 }} & \multirow{2}{*}{\multicolumn{4}{|c|}{ 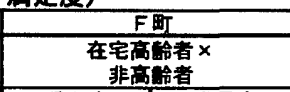 }} & \multicolumn{12}{|c|}{ 在完高跲者 } \\
\hline & & & & & & & & & & & \multicolumn{2}{|c|}{$\begin{array}{l}\text { K町 } x \\
\text { F町 }\end{array}$} & \multicolumn{2}{|c|}{$\begin{array}{l}\text { K㷁 X } \\
\text { リ八舅院 }\end{array}$} & \multicolumn{2}{|c|}{$\begin{array}{c}F \text { 町 X } \\
\text { リ八院院 }\end{array}$} & \multicolumn{2}{|c|}{$\begin{array}{c}\text { K町 X } \\
F \text { 町 }\end{array}$} & \multicolumn{2}{|c|}{$\begin{array}{c}\text { K町 } \times \\
\text { リ八病院 }\end{array}$} & \multicolumn{2}{|c|}{$\begin{array}{c}F \text { 町 } x \\
\text { リ八船院 }\end{array}$} \\
\hline & & & \multicolumn{2}{|c|}{ 畺要度 } & \multicolumn{2}{|c|}{ 葷足榣 } & \multicolumn{2}{|c|}{ 圔要度 } & \multicolumn{2}{|c|}{ 荡足度 } & \multicolumn{6}{|c|}{ 兾要度 } & \multicolumn{6}{|c|}{ 满足度 } \\
\hline & & & 在宝 & 施設 & 在宝 & 饰投 & 在宝 & 非离 & 弃宝 & 非意 & K畂 & F畂 & K畂 & 以八 & $F$ 畂 & リ八 & K町 & $F$ 畂 & K町 & 1八 & $F$ 町 & 少 \\
\hline | & 断1 & 栄原体力 & 1.33 & 1.31 & 4.31 & 4.18 & 1.17 & 1.32 & 4.31 & 3.62 & 1.33 & 1.17 & 1.33 & 1.24 & 1.17 & 1.24 & 4.31 & 4.31 & 4,31 & 3.87 & 4.31 & 3.87 \\
\hline 康 & 成2 & 角禹の序 & 1.43 & 1.37 & 4.29 & 4.46 & 1.28 & 1.43 & 4. 18 & 3.22 & 1.43 & 1.28 & 1.43 & 1.29 & 1.28 & 1.29 & 4.29 & 4.18 & 4.29 & 3.87 & 4. 18 & 3.87 \\
\hline & 间3 & 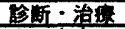 & 1.54 & 1.39 & 4.22 & 4.43 & 1.38 & 1.36 & 4. 14 & 2.85 & 1.54 & 1.38 & 1.54 & 1.53 & 1.38 & 1.53 & 4.22 & 4.14 & 4.22 & 3.89 & 4.14 & 3.89 \\
\hline 物 & 闻4 & 交立要全 & 1.53 & 1.88 & 3.90 & 3.65 & 1.39 & 1.30 & 3.56 & 2.60 & 1.53 & 1.39 & 1.53 & 1.33 & 1.39 & 1.33 & 3.90 & 3.56 & 3.90 & 3.05 & 3.56 & 3.05 \\
\hline & 問5 & 交而の便 & 1.80 & 1.67 & 3.67 & 3.18 & 1.49 & 1.67 & 4.02 & 3.29 & 180 & 1.49 & 1.80 & 1.64 & 1.49 & 1.64 & 3.67 & 4.02 & 3.67 & 3.35 & 4.02 & 3.35 \\
\hline 的 & 要6 & 自然立境 & 1.53 & 1.57 & 4.30 & 4.40 & 1.33 & 1.39 & 4. 06 & 3.15 & 1.53 & 1.33 & 1.53 & 1.68 & 1.33 & 1.68 & 4.30 & 4.06 & 4. 30 & 3.68 & 4.06 & 3.68 \\
\hline & 䁖7 & 夏间の境 & 1.36 & 1.47 & 4.48 & 4.69 & 1.39 & 1.49 & 3.98 & 3.43 & 1.36 & 1.39 & 1.36 & 1.64 & 1.39 & 1.64 & 4.48 & 3.98 & 4. 48 & 4.03 & 3.98 & 4.03 \\
\hline & 㶾8 & 公共能設 & 1.72 & 2.30 & 4.18 & 3.50 & 1.59 & 1.91 & 3.92 & 2.94 & 1.72 & 1.59 & 1.72 & 1.91 & 1.59 & 1.91 & 4. 18 & 3.92 & 4. 18 & 3.54 & 3.92 & 3.54 \\
\hline & 閣9 & 持古䆙 & 2.03 & 2.57 & 4.24 & 3.55 & 1.70 & 1.85 & 4.24 & 3.44 & 2.03 & 1.70 & 2.03 & 2.08 & 1.70 & 2.08 & 4.24 & 4.24 & 4.24 & 3.80 & 4.24 & 3.80 \\
\hline & 间 10 & 得案の磪保 & 1.88 & 2.42 & 4.18 & 3.53 & 1.79 & 2.01 & 4. 11 & 3.52 & 1.88 & 1.79 & 1.88 & 1.97 & 1.79 & 1.97 & 4.18 & 4.11 & 4.18 & 4.13 & 4.11 & 4.13 \\
\hline & 問11 & 施掫入居 & 1.89 & 1.57 & 3.72 & 3.93 & 1.69 & 1.69 & 3.74 & 2.87 & 1.89 & 1.69 & 1.89 & 1.53 & 1.69 & 1.53 & 3.72 & 3.74 & 3.72 & 3.03 & 3.74 & 3.03 \\
\hline & 酉12 & 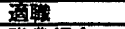 & 1.81 & 2.05 & 3.86 & 3.33 & 1.81 & 1.48 & 3.91 & 3.05 & 1.81 & 1.81 & 1.81 & 1.90 & 1.81 & 1.90 & 3.86 & 3.91 & 3.86 & 3.22 & 3.91 & 3.22 \\
\hline & 闻 13 & 謈蓁紹介 & 2.07 & 2.79 & 3.65 & 3.35 & 1.85 & 1.73 & 3. 80 & 2.69 & 2.07 & 1.85 & 2.07 & 1.95 & 1.85 & 1.95 & 3.65 & 3.80 & 3.65 & 2.90 & 3.80 & 2.90 \\
\hline & 庭14 & 巷用の安定 & 1.89 & 2.36 & 3.65 & 3.16 & 1.73 & 1.35 & 3. 82 & 2.91 & 1.89 & 1.73 & 1.89 & 1.92 & 1.73 & 1.92 & 3.65 & 3.82 & 3.65 & 2.73 & 3. 8 ? & 2.73 \\
\hline & 酉15 & +分な盯蓄 & 1.57 & 2.19 & 3.75 & 3.54 & 1.50 & 1.48 & 3.65 & 2.77 & 1.57 & 1.50 & 1.57 & 1.67 & 1.50 & 1.67 & 3.75 & 3.66 & 3.75 & 2.69 & 3.66 & 2.69 \\
\hline & 間16 & 老後の年金 & 1.40 & 1.67 & 3.82 & 3.96 & 1.52 & 1.31 & 3.83 & 2.45 & 1.40 & 1.52 & 1.40 & 1.25 & 1.52 & 1.25 & 3.82 & 3.83 & & 2.52 & 3.93 & 2.52 \\
\hline & 間17 & 䩂证 $4-t^{2} \lambda$ & 1.71 & 1.69 & 3.50 & 3.65 & 1.50 & 1.34 & 3. 76 & 2.70 & 1.71 & 1.50 & 1.71 & 1. 15 & 1.50 & 1.15 & 3.50 & 3.76 & 3 & 2.85 & 3. 76 & 2.85 \\
\hline & 间18 & 生活保障 & 1.62 & 1.63 & 3.80 & 3.90 & 1.38 & 1.36 & 3.82 & 2.84 & 1.62 & 1.38 & 1.62 & 1.20 & 1.38 & 1.20 & 3.80 & 3.82 & 3. & 3.03 & 3.82 & 3.03 \\
\hline & 间19 & 整味-教言 & 1.80 & 1.88 & 3.90 & 4.06 & 1.56 & 1.83 & 4.03 & 3.01 & 1.80 & 1.56 & 1.80 & 1.77 & 1.56 & 1.77 & 3.90 & 4.03 & 3. & 3.33 & 4.03 & 3.33 \\
\hline 化 & 問20 & クラフ入会 & 1.94 & 2.10 & 3.91 & 3.82 & 1.71 & 2.02 & 3.96 & 3.13 & 1.94 & 1.71 & 1.94 & 2.22 & 1.71 & 2.22 & 3.91 & 3.96 & 3. 91 & 3.10 & 3.96 & 3.10 \\
\hline & 廑21 & 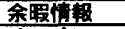 & 1.99 & 2.04 & 3.84 & 3.92 & 1.80 & 2.07 & 3.96 & 3.24 & 1.99 & 1.80 & 1.99 & 2.38 & 1.80 & 2.38 & 3.84 & 3.96 & 3.84 & 3.38 & 3. 96 & 3.38 \\
\hline 社 & 問22 & $731 n^{\circ} ;-$ & 1.73 & 1.59 & 3.92 & 4.31 & 1.52 & 1.32 & 4. 02 & 3.11 & 1.73 & 1.52 & 1.73 & 1.51 & 1.52 & 1.51 & 3.92 & 4.02 & 3.92 & 3.40 & 4.02 & 3.40 \\
\hline & 店 & 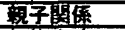 & 1.40 & 1.65 & 4.27 & 3.84 & 1.39 & 1.19 & 4. 34 & 3.84 & 1.40 & 1.39 & 1.40 & 1.25 & 1.39 & 1.25 & 4.27 & 4.34 & 4.27 & 4.11 & 4. 34 & 4.11 \\
\hline 的 & 問24 & 部方笑交流 & 1.52 & 1.56 & 4.19 & 4.10 & 1.48 & 1.65 & 4. 26 & 3.67 & 1.52 & 1.48 & 1.52 & 1.58 & 1.48 & 1.58 & 4.19 & 4.26 & 4.19 & 4.06 & 4.26 & 4.06 \\
\hline & 問 25 & 友人交流 & 1.50 & 1.61 & 4.18 & 4.02 & 1.63 & 1.54 & 4. 29 & 3.64 & 1.50 & 1.63 & 1.50 & 1.80 & 1.63 & 1.80 & 4.18 & 4.29 & 4. 18 & 3.84 & 4.29 & 3.84 \\
\hline & 䁬26 & 近所交流 & 1.57 & 2.04 & 4.16 & 3.82 & 1.68 & 2.04 & 4.05 & 3.45 & 1.57 & 1.68 & 1.57 & 1.94 & 1.68 & 1.94 & 4.16 & 4.05 & 4.16 & 3.67 & 4.05 & 3.67 \\
\hline 地 & in 27 & 地域活好 & 1.74 & 2.18 & 3.96 & 3.38 & 1. 72 & 2.08 & 3.96 & 3.25 & 1.74 & 1.72 & 1.74 & 2.14 & 1.72 & 2.14 & 3.96 & 3.96 & 3. 96 & 3.25 & 3.90 & 3.25 \\
\hline & 间28 & 地地行 & 1.77 & 2.04 & 4. 14 & 3.88 & 1.81 & 2.36 & 4.09 & 3.33 & 1.77 & 1.81 & 1.77 & 2.22 & 1.81 & 2.22 & 4.14 & 4.09 & 4. 14 & 3.52 & 4.09 & 3.52 \\
\hline 的 & 痁29 & 会舩保奔 & 1.86 & 1.94 & 3.76 & 3.29 & 1.77 & 2.00 & 3. 79 & 3.22 & 1.86 & 1.77 & 1.86 & 2.25 & 1.77 & 2.25 & 3.76 & 3.79 & 5. & 3.15 & 3. 79 & 3.15 \\
\hline & 画30 & 住民皇加 & 1.61 & 1.84 & 3.85 & 3.14 & 1.52 & 1.59 & 3.71 & 2.86 & 1.61 & 1.52 & 1.61 & 1.66 & 1.52 & 1.66 & 3.85 & 3.71 & 3.85 & 2.61 & 3.71 & 2.61 \\
\hline
\end{tabular}


「問 18 生活保障」の経済的環境であり、通院による医療費の負担 等から起因した評価であると思われる。リ八病院高龄者の重要度が 低い項目は、「問 6 自然環境」「問 7 夜間の環境」「問 20 クラブ 活動」「問 21 余层情報」「問 26 近所交流」「問 27 地域活動」「問 28 地域行事」「問 29 伝統保存」で、文化的環境亡地域的環境の項 目が多く、障害との関連が比較的少ない項目の評価が低い ${ }^{23)}$ 。

満足度評価では、「問 3 診断・治療」「問 10 個室の確保」「問 23 親子関係」「問 24 親族交流」以外の項目で、リ八病院高龄者と $\mathrm{K}$ 町 $\cdot \mathrm{F}$ 町在宅高龄者の差がみられ、経済的環境、文化的噮境、地 域的環境の全項目でリ八病院高龄者の満足度が低い。とりわけ、「福 祉サービス」は重要度が高く満足度が低いという結果であり、リハ 病院高跉者への福祉サービスの充実が求められているとともに、図 2 の高齡者の「福祉サービス」の評価には、リ八病院高齢者の評価 が大きく影響していることがわかる。リ八病院高㱓者と $\mathrm{K}$ 町・F 町 在宅高齢者の生活環境評価における顕著な違いは、リ八病院の調査 対象者は通院中の高跉者であること、主観的 QOL は障害の受容と 深い関係が指摘されていること ${ }^{24)}$ 、地域特性が異なる $\mathrm{K}$ 町・F 町 両地域と平均值の差がみられること等の理由から、「健康状態（特 に手足の障害）」という属性の違いが起因していると思われ、在宅 高路者間の主観的な生活環境評価には、健康状態が大きく影響して いることが推察される ${ }^{25)}$ 。

なお、 $\mathrm{K}$ 町と $\mathrm{F}$ 町の在宅高㱓者間では、重要度では「問 5 交通の 便」「問 18 生活保障」、满足度では「問 7 夜間の環境」に差がみ られた。「交通の便」「夜閒の環境」は既成市街地と農山村地区と いう地域の違い、「生活保障」は世帯規模の違いからきたものと思 われる。

\section{4. 住珢境評価の結果}

\section{4-1. 高䍅者の住㻴境評価}

高齢者の住環境評価をみると（図 4）、重要度の各項目の中央値 は「とても重要である」「やや重要である」という肯定的な評価が 多い。满足度では「問 26 空間確保」の評価がやや低いものの、各 項目の中央值は「やや満足している」という肯定的な評価が多数で あり、重要度・満足度ともに図 2 の生活環境評価と類似した傾向を 示している。

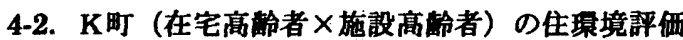

重要度評価で平均值に差がある項目は「問 35 整報器の有無」の みであり（表 8)、在宅高歯者の評価が高い。満足度評価では、「問 5 手すりの有無」「問 7 ドアの開閉」問 11 夜間スイッチ位置」「問 13 祭急連絡」「問 22 手すりの有無」「問 23 急激な温度差」「問 27 洗濯機利用等」「問 32 トイレの位置」で施設高龄者の満足度が 高く、施設内はバリアフリー仕梯であること、個室内にトイレが設 置されていること、祭急時には尞母室と連絡がとれること、等の施 設の住環境を反映した結果となっている。

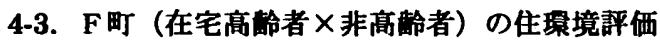

重要度評価で平均値に差がある項目では、在宅高歯者の評価が高

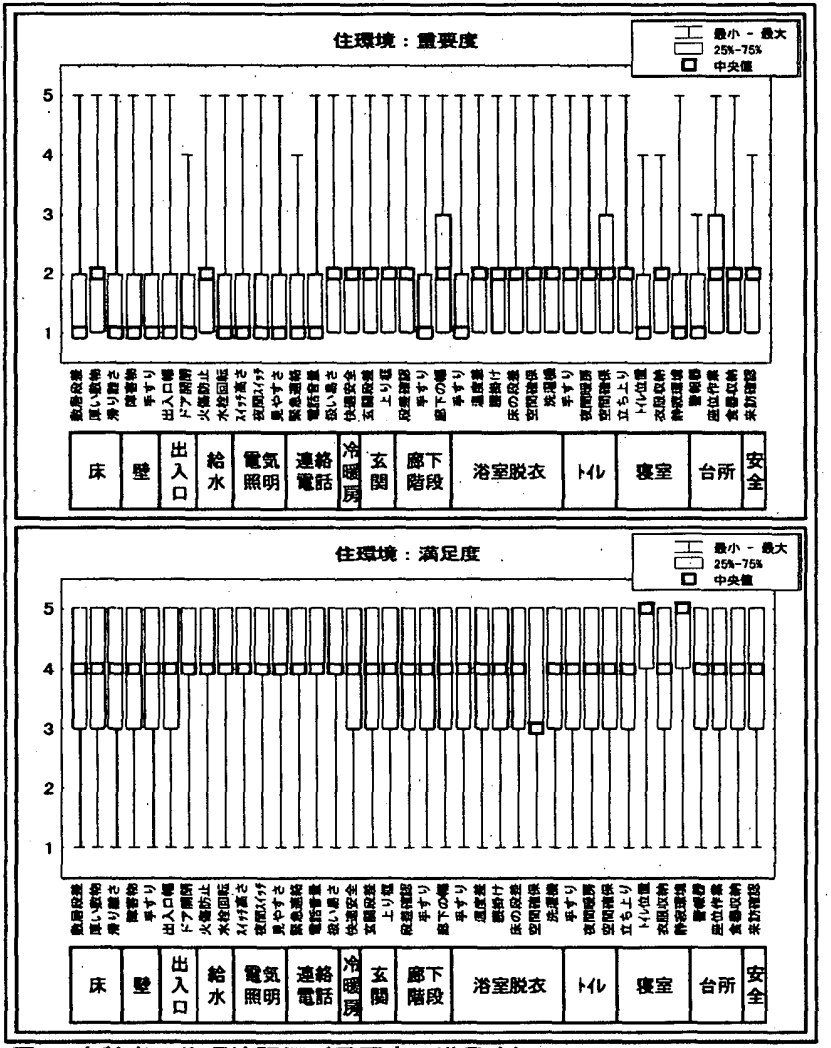

图4 高䑪者の住環境㟽価（重要度・満足度）

く（表 8）、重要度が高い項目では満足度も高い傾向を示している。 また、生活環境評価同様、満足度では明らかな差がみられ、ここで も在宅高齢者の評価が高い結果となっている。

\section{4-4. 在宅高跲者間（K町 $\times F$ 町 $\times$ y八病院）の住渨境評価}

住環境評価の平均值の差を相対的みると（表 8）、 $\mathrm{K}$ 町と F 町の 在宅高龄者間では、重要度は F 町在宅高㱓者の評価が高いものの、 満足度評価の差はみられない。 $\mathrm{K}$ 町とリ八病院高龄者間では、重要 度はリ八病院高踰者の評価が高く、満足度は逆に K 町在宅高跲者の 評価が高い。また、F 町とリ八病院高龄者間でも重要度評価の差は みられないものの、淦足度は $\mathrm{F}$ 町在宅高龄者の評価が高い。以上の ことから、 $\mathrm{K}$ 町・ F 町の在宅高制者に比ベてリ八病院高跉者の住環 境に対する評価は、重要度が高く满足度が低い傾向がみられ、リハ 病院高齢者の住環境の整備が求められているとともに、生活環境評 価同様、主観的な住環境評価にも健康状態が影響していると推察さ れる。

\section{5. 生活㻴境評価と住珢境評価の関俰}

生活環境総合満足度評価と住睘境総合満足度評価をみると（図

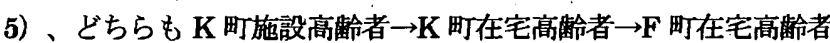
$\rightarrow$ リ病院高踰者 $\rightarrow \mathbf{F}$ 町非高龄者の順に評価が下がっており、 $\mathrm{K}$ 町 施設高砱者・ $\mathbf{K}$ 町在宅高龄者・ $\mathbf{F}$ 町在宅高跲者の集団とリ八病院高 跉者・F 町非高跲者の集団での差がみられる。また、各集団ともに 図 5 の箱ヒグ図は類似した位置関係になっており、生活環境総合満 足度評価と住環境総合満足度評価には関係がみられる。そこで、生 


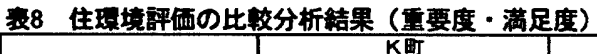

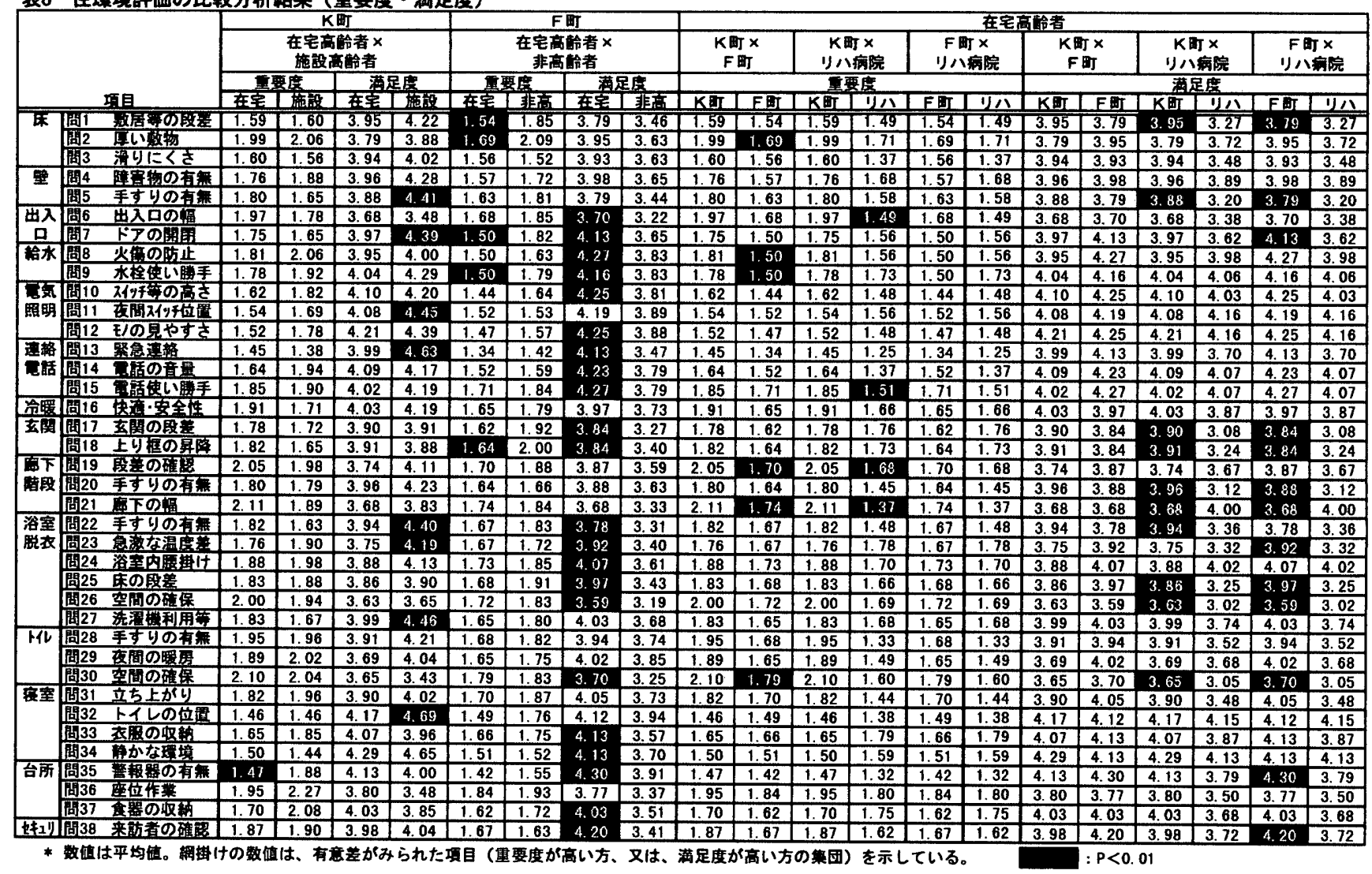

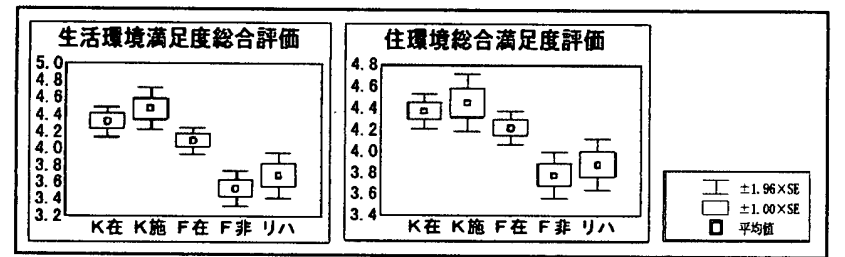

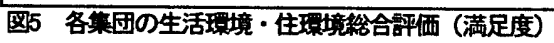

活環境評価と住環境評価の関係を調べるために、まず、各集団別に 各住環境評価項目と生活環境総合評価のクロス集計を行い、クロス 集計毎にカイ 2 乗検定を行った（表 9）。なお、ここでは有意水準 $5 \%$ 末満 $(\mathrm{P}<0.05)$ の項目について考察している。

住環境総合評価と生活環境総合評価では（問 39）、すべての集団 で住環境総合評価が高い場合は生活環境総合評価が高いという評価 間の関係が認められた。また、各住環境評価項目と生活環境総合評 価との有意差がみられた項目数（以下、有意項目数）と有意項目割 合（有意差がみられた項目数／全項目数）を各集団別にみると、F 町在宅高齢者 (35 項目·92\%) $\rightarrow \mathrm{K}$ 町在宅高齢者（33 項目・87\%） $\rightarrow \mathrm{F}$ 町非高龄者 $(27$ 項目·71\%) $\rightarrow$ リ八病院高跉者 $(24$ 項目・63\%) $\rightarrow \mathrm{K}$ 町施設高㱓者 (12 項目・32\%) の順に有意項目数が诚少してお り、在宅集団と非在宅集団の有意項目数の違いがみられる。また、 在宅集団内でも健康な在宅集団群の有意項目数が多い。

次に、各集団別に各生活環境評価項目と住環境総合評価のクロス 集計を行い、クロス集計毎にカイ 2 乗検定を行ったところ (表 10) $\mathrm{K}$ 町在宅高齢者 $(29$ 項目 $\cdot 97 \%) \rightarrow \mathrm{F}$ 町非高路者 $(17$ 項目 $\cdot 57 \%) \rightarrow$ $\mathrm{F}$ 町在宅高龄者 $(15$ 項目 $\cdot 50 \%) \rightarrow \mathrm{K}$ 町施設高跲者 (11 項目・33\%)
表9 各集団の各住懪焼秤洒と生活 環境稳合評価の力12乗梌定 (满足度)

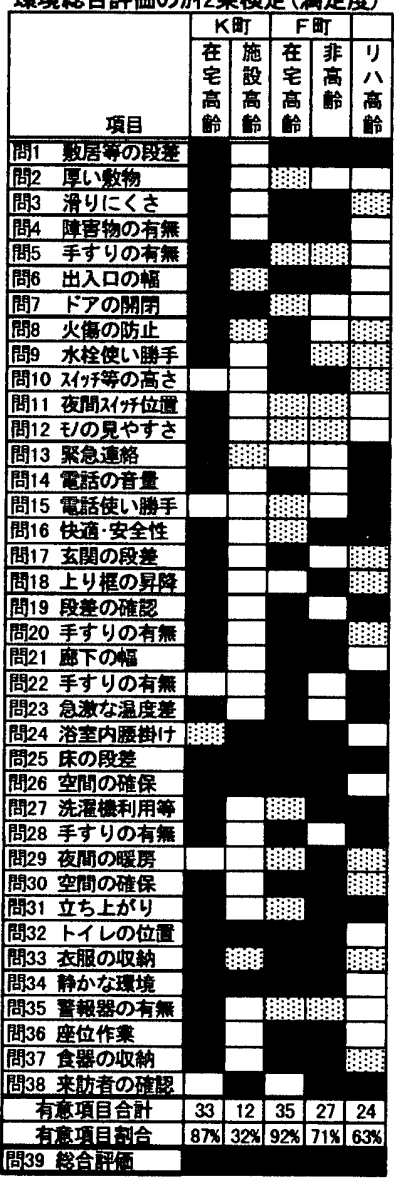

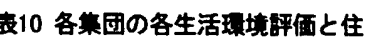
環境淞合評価の力12垂捈定 (满足度)
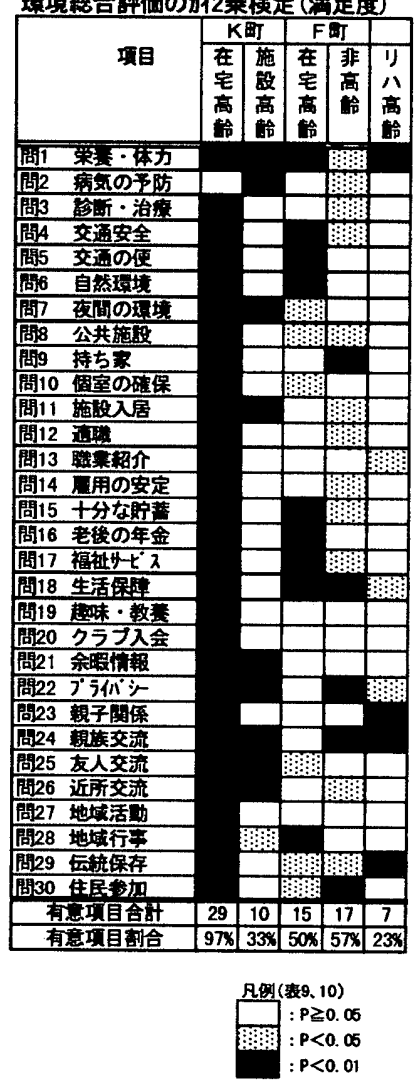


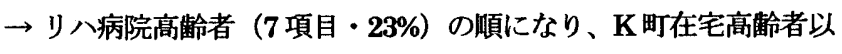
外の集団では表 9 よりも有意項目数はほとんど减少している。

以上の結果から：各集団ともに生活環境評価と住睘境評価の関俰

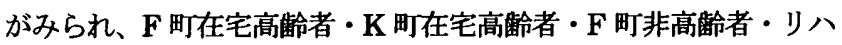
病院高齢者の各集団については、表 10 (各生活環境評価項目と住環 境総合評価の関俰) よりも表 9 (各住環境評価項目と生活噮境総合 評価の関係）の方が有意項目数が多いことから、住環境の改善が生 活環境総合評価を向上させる可能性を示すものと考えられる。なお、 K町施設高跲者の場合は、すでに表 8 でみたように、住環境の満足 度が高いために生活環境総合評価との関係が少ないと考えられ、生 活環境の総合的な満足度を得るためには、表 $7 \cdot 8$ の在宅高制者と の比較分析結果を考慮した包括的なアプローチが必要であると思わ れる。

\section{6. まとめ}

本稿では、在宅高齢者・施設居住高齡者・リハビリテーション病 院通院高龄者及び非高龄者の各集団の生活壊境と住環境に関する主 観的な評価を基に、各集団の生活環境と住環境の評価の実態を把挃 し、評価の違いが生じる要因を探るとともに、生活環境評価と住環 境評価の関係について考察した。以下にその内容を要約する。

1) 生活環境評価

・高齢者の傾向としては、健康的環境と社会的環境が重要事項で あり、福祉サービスに不満を感じている高龄者が多い。また、

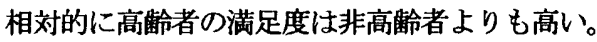

- K 町 (在宅高跉者 $\times$ 施設高龄者) では、自分の家を持つこと、 可能な限り仕事を続けること、金銭的に余裕を持つこと、地域 の人々とふれあいながら生活すること、等を在宅高制者が重要 視している。施設高踰者は地域的環境の満足度が低く、転居後 の地域社会への参加が難しい現状にある。

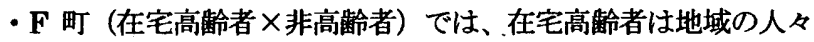
との交流を重要視しており、在宅高龄者は非高龄者よりも生活 環境の満足度が高い。

- 在宅高踰者間 (K 町 $\times \mathrm{F}$ 町 $\times$ リ八病院) では、重要度・満足度 ともにリ八病院高龄者の評価が低く、「健康状態（特に手足の 障害）」の違いが評価に影響している。少数の項目ではあるが、 $\mathrm{K}$ 町と $\mathrm{F}$ 町地域特性の違いによる評価の差もみられる。

2）住環境評価

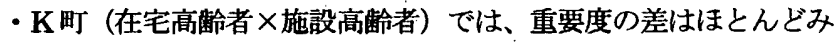
られないものの、満足度は施設高龄者の評価が高く、施設の住環 境を反映した結果となっている。

- F 町 (在宅高龄者 $\times$ 非高齢者) では、重要度・満足度ともに在 、宅高路者の評価が高く、とりわけ、満足度は生活環境評価同様、 在宅高齢者と非高龄者の評価に明らかな差がみられる。

- 在宅高齢者間 (K町 $\times \mathbf{F}$ 町 $\times$ リ八病院) では、リ八病院高龄者の 評価は重要度が高く満足度が低い傾向がみられ、リ八病院高龄者 の住環境の整備が求められているとともに、生活環境評価同様、 健康状態の違いが評価に影響していると推察される。

3）生活噮境評価と住環境評価の関保
・すべての集団で、住環境総合評価が高い場合は生活噮境総合評価 が高いという評価間の関係が認められた。

- $\mathrm{F}$ 町在宅高龄者・ $\mathrm{K}$ 町在宅高齢者・F町非高齢者・リ八病院高齢 者の各集団については、住環境の改善が生活環境総合評価を向上 させる可能性がみられたが、 $\mathrm{K}$ 町施設高㱓者の生活環境総合評価 の向上には、さらに包括的なアプローチが必要であることが示さ れた。

4) 今後の課題

・本稿では、(1)生活環境評価と住環境評価は、主観的な評価を総合 的に探るための一般論的な設問からの検討に留まっており、F 町

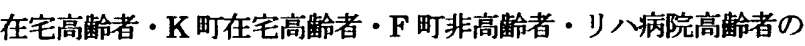
各集団については、住環境改善による生活環境評価への影響を探 るとともに、 $\mathrm{K}$ 町施設高龄者の生活環境評価向上のための方策を 探る必要があること、(2)調查票の信頼性と妥当性の検討が必要で あること、(3)リ八病院高制者については、同一地域内の高齢者と の比較検討が必要であること、等が検討されておらず、今後の課 題としたい。

領辞 本稿をまとめるにあたり、調查の機会の提供をしていただいた施 設・病院関係者、並びに調查に御協力いただいた方々に御礼申し上げます。 また、リハビリテーション分野のQOLに関する御助言をいただいた横浜 市立大学医学部教授・安藤徳彦先生、分析方法の御助言をいただいた成蹊 大学経済学部教授・新村秀一先生に哚謝申し上げます。

\section{参考文蔐}

1）青井和夫他編：生活構造の理論、有斐閣、1971

2) 青木志郎、本間博文 : 住要求の構造に関する研究 (第 1 報)、日本建 筑学会論文報告集第 247 号、1976

3）青木志郎、本間博文 : 住要求の構造に関する研究（第 2 報）、日本建 築学会論文報告集第 248 号、1976

4）安藤徳彦他 : 高踰者骨関節疾患の QOL に関する研究、長寿科学総合 研究、平成 6 年度研究報告書 Vol6、1995

5）上田敏 : ADLから QOLへ、総合少第 12 巻 4 号、1984

6）大川跼雄 : クオリティ・オブ・ライフのリ八医学における評価、総合 リ八第 12 巻 4 号、 1984

7）大橋正洋：心理テストとQOL、総合リ八第 15 巻 12 号、1987

8）荻原俊男編：老年病とQOL、医薬ジャーナル、1996

9）梶秀樹 : 生活環境に対する住民満足感の構造に関する研究、日本建築 学会論文報告集第 165 号、1969

10）金子勇 : 都市高齢社会と地域福祉、ミネルバ書房、1993

11）高踰化対応住宅リフォームマニュアル、日本住宅リフォームセンター、 1994

12）新村秀一 : パソコンによるデータ解析、講談社、1995

13）高橋正樹、宮田紀元 : 住宅の居住後評価の実態と評価に影響する要因、 日本建築学会論文報告集第 488 号、1996

14）都留重人他編 : クオリティ・ライフ、弘文堂、1983

15）中島照夫 : 痴呆疾患患者のQOL とその客観的評価基準に関する研究、 長寿科学総合研究、平成 6 年度研究報告書 Vol6、1995 
16）中島義明他編: 人間行動学講座 3 すまう一住行動の心理学、朝倉書店、 1996

17）原鉄哉 : 高路者·障害者の住宅改造、理学療法の歩み第 7 号、1996

18）山口明 : 在宅障害者の地域におけるQOL、総合リ八第 15 巻 12 号、 1987

19) Bergmer, $M$, et al., The sickness impact profile: Development and final revision of a health status measure. Medical Care, 19, 1981.

20) Duke University Center for the Study of Aging and Human Development. Multidimensional functional assessment. The oars methodology. Durham, N.C., 1978.

21）Guggenmoos HII 他編、篗畸一朗他訳 : QOL一その概念から応用まで、 シュプリンガー・フェアラーク東京、1996

22) Hunt SM, et al, A quantitative approach to perceived health status: A validation study. J Epidemiol Comm Health, 34, 1980.

23）James E. B 他編、三谷嘉明他訳 : 虚弱な高舲者のQOL、医菌薬出版、 1998

注

1）青木らは「空間に対する価值はそれ独自に決定されるのではなく、人 間の生活の中の空間以外の様々な側面、例えば、労働条件や経済状態、 生活時間の配分状況やコミュニケーション等との相互の関係の中で決 定されている」と述へている（参考文献 2)。

2）参考文献 14、119 142 頁。

3) Nottingham Health Profile : ヘルスケアのニードを探ることが目的で あり、45 項目で構成されている（参考文献 22）。

4) Sickness Impact Profile : 慢性疾患が患者の QOL や活動機能に及ぼす 影響を評価することが目的であり、136 項目で構成されている（参考文 献 19）。

5) Older American Resources and Services : 高秢者の活動機能を測定し、 プログラムの評価と資源配分を指針を得ることが目的であり、70 項目 で構成されている（参考文献 20）。

6）例えば、痴呆疾患高龄者のQOLについては参考文献 14 等、骨関節疾 患高鈴者のQOLについては参考文献 4 等がある。

7）安藤はリウマチを中心とする骨関節疾患の治療効果を判定するために 開発された QOL 測定法の指標を紹介し、「QOL とは称しながら、そ の項目は日常生活動作（ADL）とその延長線上の指標が使用されてい る。（中略）治療効果をより鋭敏に反映する指標に注意が集中して、 QOL の真の意義が忘れ去られ、QOL の概念を崩壊させる原因にもなり かねないと指摘している（参考文献8、73〜74 頁）。

8）参考文献 $21 、 128 \sim 141$ 頁。

9）参考文献 9

10）参考文献 $2 、 3$

11）参考文献 13

12）本稿では、生活要求を探る手法としてQOL 測定法の指標を参考にし ているが、注記 7.8 の指摘を踏まえて、基本的にはQOL という表現で はなく生活環境という表現を用いている。但し、引用文等が関保する場 合にはQOL という表現をそのまま用いている。

13）調査対象としたリハビリテーション科をもつ病院は 7病院（宫城県 3
ケ所・福節県 3 ケ所・東京都 1 ケ所) である。

14）「A 市統計書平成 7 年度版」から引用した。

15）「QOL を論ずる場合に重要なのは、いかに QOL を評価するかでは なく、いかにQOLを向上させるかという実践的な課題として捉えるこ とである。どのような評洒法をとるかも、何を目的にするかで定まる」 という指摘を踏まえ（参考文献 $8 、 107$ 頁）、本研究の生活環境の調查 内容は、(1)山口の在宅障害者（平均年齢 66 歳）のQOLに関する研究 が、障害の有無から QOLを比較検討するという点において本研究と近 似していること（参考文献 18）、(2)本研究の結果と(1)の報告結果を比 較検討すること、(3)高齢者の住みごこちのよさを探ること（参考文献 10）等の理由から、山口が用いた「国民生活選好度調查（経済企画庁 国民生活局調查課、昭和 59 年度）」の指標と金子の「都市アメニティ」 の指標とを併せて検討して作成した。また、評価テストの開発方法は参 考文献 7、評価方法は参考文献 6 をそれぞれ参考にした。

16）住璄境の調查内容は、参考文献 11、17を参考にして作成した。

17）多重比較の方法は、LSD 検定を用いた。

18）参考文献 8、76 79 頁。

19）高齡者は疾患や障害をもつことが多く、心身のマイナス面に目が向け られがちであるが、この結果は、疾患や障害はその高龄者の一部分であ り、他の潜在的なプラス面の育成等により、主観的に高い満足度を得る ことが可能であることも意味していると思われる(参考文献 81108頁)。 20）例えば、外山は施設内空間の領域性についてけず個が守られる空間、 次に数名の個が共有できる空間、小規模なグループのまとまりの単位、 そして施設全体といったように生活領域を段階的に組み立て直す」とと を提案している（参考文献 16、219 頁）。

21）参考文献 8、71 頁。

22）自身の過去を肯定したい等の心理的結果ともいわれている（参考文献 8. 79 頁)。

23）山口の QOL に関する研究報告でも（参考文献 18）、在宅障害者の QOLの閣心については「健康・医療、家族関係、眝蓄や年金などの生活 保障にあり、地域社会活動などへの参加はその機会も狭められており、 社会的役割機能に関しては関心の度合も低いと指摘されている。

24）参考文献 8、113 120 頁。

25）本研究での高龄障害者と非高龄障害者の評価の違いは、山口の研究報 告の結果（参考文献 18）よりも顥著な差がみられる。

(1999年 3 月 2 日原稿受理， 2000 年 3 月 2 日採用決定） 